\title{
Fiction with an \\ Iowa City Setting: \\ An Updated Checklist
}

EARL M. ROGERS

\section{Iowa City and The University of Iowa}

have been home for many writers. The Iowa Writers' Workshop and the International Writing Program are at present the best-known cultivators of writing on the University campus. But student publications, especially the Iowa Literary Magazine (1924-30), and the encouragement of writers by the Department of English are traditions that began much earlier. Students, professors, and visitors have sometimes turned to the local scene for their subjects. This checklist is an expansion and revision of a 1986 article in Books at Iowa. ${ }^{1}$

Many works fall into the category of academic novels, primarily about students or professors. Published studies and bibliographies of academic novels list several UI novels and supply a context for them. ${ }^{2}$ The University of Iowa Hospitals and Clinics, which forms a large part of the Iowa City community, has also provided subjects for novelists. Athletics and

${ }^{1}$ Earl M. Rogers, "Fiction with an Iowa City Background: An Annotated Checklist," Books at lowa 44 (April 1986): 10-26; and Carolyn Rushton, "In Mr. Rogers' Neighborhood," Iowa City Magazine 1, no. 1 [September 1989]: 9, 11.

${ }^{2}$ John E. Kramer, Jr., 'The Actual Settings of American 'College Novels' and 'College Mysteries,"' Literary Research Newsletter 10, no. 3 (Summer 1985): 5-35; John E. Kramer, Jr., The American College Novel: An Annotated Bibliography (New York: Garland, 1981); John E. Kramer, Jr., and John E. Kramer III, College Mystery Novels: An Annotated Bibliography, Including a Guide to Professional Series-Character Sleuths (New York: Garland, 1983); John O. Lyons, The College Novel in America (Carbondale: Southern Illinois University Press, 1962); John O. Lyons, "The College Novel in America: 1962-1974," Critique: Studies in Modern Fiction 16, no. 2 (1974): 121-28; and Von V. Pittman, Jr., and John M. Theilmann, "The Administrator in Fiction: Portrayals of Higher Education," Educational Forum 50 (Summer 1986): 405-18. 
homosexuality are becoming new topics for local literary exploration, once in the same novel (it would be unfair to reveal which one).

Many of these novels bring out-of-state visitors to the University or the city, giving their writers an opportunity to comment on local characteristics or problems. In many of the novels of the sixties and later decades, several patterns can be discerned. Counterculture sexual behavior, drugs, student demonstrations, avaricious landlords, farmhouses, and Volkswagens can be anticipated as almost a set formula. The downtown Iowa City urban renewal project continues to be severely criticized, both for the closing of Harold Donnelly's and Irene Kenney's bars and for the allegedly poor architectural quality of the new buildings. Several writers who refer to Meredith Willson, author of The Music Man, mistakenly assume that his "River City" refers to Iowa City, not Mason City, and all of them misspell his name as "Wilson." Old Capitol, the University's central building and symbol, unsurprisingly, is almost always in the background. The University president, for whatever reasons, is rarely mentioned in Iowa City novels, unlike novels set at other academic institutions. Local places and people may be portrayed with their real names but more often they are disguised. Writers sometimes make obvious factual errors, though these gaffes do not usually detract from their stories.

The current reputations of the following authors seem to stand in direct proportion to the quality of their writings. Vance Bourjaily's Now Playing at Canterbury is probably the best novel for description of Iowa City and the University and for portraying the state of mind of its characters. Philip Roth's Letting Go and John Irving's The World According to Garp are important novels with comparatively little on Iowa City. The athletic novels by David Shields and W. P. Kinsella are more entertaining to read than most on the list. Elizabeth Hardwick has the 
best lines about reactions to Iowa City; her comments should be compared to nonfiction articles by John Cheever and others. ${ }^{3}$

The novels, poems, short stories, and creative writing dissertations listed below are set, at least in part, in Iowa City. The annotations concentrate on the Iowa City settings rather than on character development or literary value. I am grateful to the many people who gave me leads to the following works; their interest and assistance are appreciated. ${ }^{4}$ Several printed sources have also been useful in identifying Iowa City fiction. ${ }^{5}$ Only a few examples from International Writing Program participants have been found. The compiler alone is responsible for omissions and errors of interpretation. Additions will be welcomed.

Agee, Jonis. SWEET EYES. New York: Crown, 1991. 405 pp.

Divinity, a small town in Iowa on the Mercy River, is about to celebrate its centennial. The characters remember a local murder and other events in the sixties. The young people then visited Des Moines, Iowa City, and Spirit Lake. "We'd heard the stories about how wild it was getting in Iowa City with hippies and radicals."

A high school student and her friend sat in on a history class in Iowa City. "I remember once I cut school and went over there, just Clinton and me, and he took me right onto campus,

3John Cheever, "An Afternoon Walk in Iowa City, Iowa," Travel \& Leisure (American Express) 4, no. 9 (September 1974): 32-33, 50; Calvin Kentfield, "State University of lowa," Holiday 34, no. 5 (November 1963): 88-91, 140-42, 144-48, 151, also in This Is lowa: A Cavalcade of the Tall Corn State, edited by Clarence A. Andrews, pp. 269-85 (Iowa City: Midwest Heritage, 1982); Laurence Lafore, "In the Sticks," Harper's Magazine 243, no. 1457 (October 1971): 108-9, 112-15; and Philip Roth, "Iowa," Esquire 58, no. 6 (December 1962): 132, 240, 242-44, 247-48, 250.

${ }^{4}$ I acknowledge Clarence A. Andrews, Dale M. Bentz, John Birkbeck, Jeanette Carter, Jacqueline Cartier, Frederick Crane, Harold Eastman, Marsha Forys, Jim Harris, James Kaufmann, David Kinnett, Nancy Kraft, Seymour Krim, John Leggett, Robert A. McCown, Thomas Newsom, Frank Paluka, Mary Parden, Von V. Pittman, Jr., Margaret Richardson, Susan H. Rogers, Miriam Runge, David Schoonover, John N. Schacht, Alan M. Schroder, Keith Swigger, Frank H. Thompson, Jr., Stephen Wilbers, and Phyllis B. Zeller.

5mong them, "Summer Reading for Iowa Citians," Prairie Grass (Iowa City) 3, no. 2 (March 1978): [8]. 
walking directly to this big gray stone building, inside, up the stairs and down the hall, and right into the back of this class that was just starting. Up in front there was this guy wearing a plaid shirt and a pair of jeans tucked into hunting boots. I guessed he was the teacher because he was the one talking, but you wouldn't know it from anything else, except maybe the pipe he kept playing with."

A rich fat man in Divinity is named Leigh Hunt. The author may have taken the name from the poor thin English literary figure whose works are collected by The University of Iowa Libraries.

Alvarez, Carlos. REFLEJOS EN EL IOWA RIVER:

DIVERTIMENTO EN TONO MENOR. Madrid: Editorial Orígenes, 1984. 77 pp.

A Spanish student in the International Writing Program publishes poems inspired by such subjects as the river, the Iowa City bus station, the Johnson County jail, the Bijou theater, and the Mayflower apartments.

Barza, Steven Lee. SCISSORS, PAPER, ROCK: A NOVEL. Ph.D. dissertation, University of Iowa, 1975. 348 pp.

Here is a novel apparently set in but not really about Iowa City. One major character teaches at Casehill College and rents a farmhouse in Amishland, on the highway beyond the Joetown flat. Except for the Inner City Revival Program and its streets blocked for repaving, the town, Stockton, in central Illinois, does not physically resemble either Iowa City or the genuine Stockton in Illinois near Galena.

Beachy, Stephen Eric. THE WHISTLING SONG. New York: Norton, 1991. 411 pp.

Matt, an orphan from Des Moines, is placed at the East Liberty Home for Boys. The boys "were not forgotten. Every Halloween they came, busloads of sorority girls from the university, to help us carve smiling or snarling faces in pump- 
kins. The local television station was close behind, dutifully recording this heartwarming scene of philanthropy for all to see." The novel is expanded from Beachy's M.F.A. thesis, Iowa, 1990.

Berryhill, Clint. TAKE A CHANCE ON ME. Fayette, la.: Iowa Authors Publishing Company, 1983. 268 pp.

An Iowa country doctor set his first novel at the University in lowa City. A rape victim and her rescuer, both freshman athletes from farm families, meet through violence and find love. The author's philosophizing overwhelms his characters' speech. Physicians at the University Hospitals are praised highly; lawyers fare less well.

Birkbeck, John. DONNELLY'S BEVERAGE: POEMS. Edited by Sue Rogers. Photography by Steve Moon. Iowa City: Left Bank Press, 1976. 51 pp., illus.

The poems are set in the former Donnelly's bar or are about people in Iowa City.

Blaise, Clark. LUSTS. Garden City, N.Y.: Doubleday, 1983. $253 \mathrm{pp}$.

Philip Roth, then only 28, leads a story discussion in the Iowa Writers' Workshop in this novel by Clark Blaise, who both studied and taught in the Workshop. The hero spends two years in Iowa City in the early sixties, a crucial interlude in a life stretching from Pittsburgh through Kentucky and New York to India. His life is changed forever in Iowa when a splinter on a library table severs an artery. Shortly before that painful event, he headed "uphill to Kenney's Bar, where the writers hung out, and over pitchers of beer and schooners of popcorn," they "would batter each other silly with opinions, with trivia, with judgments. We found all the soft spots in allegedly great stories." Clark Blaise is now director of the International Writing Program and husband of author Bharati Mukherjee. 
Bourjaily, Vance. NOW PLAYING AT CANTERBURY. New York: Dial Press, 1976. 518 pp.

Bourjaily, formerly of the Iowa Writers' Workshop, uses State University, State City, along the State River, as the setting for a novel centered around the opening of a new auditorium in 1972. (The new Hancher Auditorium on The University of Iowa campus was dedicated in 1972.) Several professors (one of whom, like the author, owns a farm near the town) and students produce a new opera and live the antiwar protests of the sixties and early seventies. Former Territorial [Old Capitol], "that lovely, calm, gold-domed antique building," watches the battles in the streets. Students occupy the office of tall, scholarly President Lawrence Esterhart and try to prevent a Dow Chemical interview. "Half the Value for Twice the Rent" is the landlords' first commandment according to the students who live on one block, and the description of their housing confirms every complaint.

Boyle, T.C. THE WOMEN'S RESTAURANT. Penthouse 8, no. 9 (May 1977): 112-14, 128, 130, 132, 134. Also, as “A Women's Restaurant," in T. Coraghessan Boyle, Descent of Man, pp. 83-98. Boston: Little, Brown, 1979. 219 pp.

Grace and Rubie's on North Linn Street in Iowa City in the mid-seventies inspired a short story about a man determined to eat in their restaurant. "It is a women's restaurant. Men are not permitted. Women go there to be in the company of other women, to sit in the tasteful rooms beneath the ancient revolving fans and the cool green of spilling plants. ..."

Bradbury, Malcolm. STEPPING WESTWARD. Boston: Houghton Mifflin, 1966. 390 pp.

The English university professor and novelist Malcolm Bradbury writes about an English novelist visiting an American university that in no way resembles Iowa. However, on the boat train and ocean liner to America, the fictional novelist meets a girls' college bagpipe band returning from a European tour. "It was a great success. They have had enormous 
audiences in Paris and Rome and Salzburg and Vienna and London. Europe is fascinated by American girls playing the bagpipes." Scotland also enjoyed the pretty girls with bare knees. (From 1952 through 1968, Iowa's Scottish Highlanders toured Europe every four years.)

Browne, Michael Dennis. LOSING WSUI. In his The Wife of Winter, pp. 17-18. London: Rapp \& Whiting, 1970. 48 pp. Also in his The Wife of Winter, pp. 13-14. New York: Scribner, 1970. $120 \mathrm{pp}$.

Browne's collected poems include one regretting the departure of the late Larry Barrett, musical announcer for "University Radio WSUI." Barrett became music critic for the Evening Star newspaper, Washington, D.C.

Buckley, William F., Jr. THE ELLINGTON AFFAIR. TV Guide 36, no. 34 (August 20, 1988): 26-27, 299-32, col. illus.; no. 35 (August 27, 1988): 34-39, col. illus.

The short story by the conservative writer is about the efforts to keep a third-party candidate out of a scheduled televised presidential campaign debate in 1992. The third-party (Peace Now!) candidate is Iowa farm boy, war hero, and millionaire businessman Lemuel S. Ellington III. In the first half of the story (August 20, page 31), Ellington's education is described: "Simultaneously he did graduate work at the University of Iowa, where, during his five years of night work. . . He earned a doctor's degree in theological studies. ..."

Calderwood, Carmelita, and James Hearst. BONESETTER'S BRAWL. Ardmore, Pa.: Dorrance, 1979. 144 pp.

Murder in the orthopedics department of a university hospital is the subject of a mystery by Carmelita Calderwood, once a nurse in The University of Iowa Hospitals and Clinics and coauthor of the textbook, Orthopedic Nursing. She was the first wife of the late James Hearst, distinguished Cedar Falls poet. After her death and Hearst's later remarriage, the second Mrs. 
Hearst found the manuscript of Carmelita's novel and it was completed for publication by Mr. Hearst. The time is August and September of 1941 and the place is a university campus with a few local names in recognizably altered form, such as the State River dividing the hospital from the Union and east campus. The Bonesetter's Brawl is the annual orthopedics dance.

Calhoun, Mary. KATIE JOHN AND HEATHCLIFF. New York: Harper \& Row, 1980. 154 pp.

The "Black Angel-a bronze monstrosity that had turned black instead of patinaed green . . ." is located in the cemetery of a Mississippi River town in Missouri in this juvenile novel of a girl's first romance. Iowa City's Black Angel is a statue in Oakland Cemetery and the subject of local folklore.

Carrier, Warren. THE HUNT. New York: New Directions, 1952. 208 pp.

Fugitives make an unscheduled stop when "at a little past midnight they broke a shock absorber on Iowa City potholes and everything was closed for the night and they tried to sleep in the car, dozing fitfully and the police car that flashed a light on them and the cop who wanted to give them a ticket for parking overnight and were they students at SUI and in the morning they took the car to the garage and had breakfast at the Princess Cafe and wandered over the great lawns of the university and picked up the car at noon and raced west again. ..."

Casey, John. AN AMERICAN ROMANCE. New York: Atheneum, 1977. $321 \mathrm{pp}$.

Theater and film on the fringes of The University of Iowa provide the setting for this novel of the 1970s. West Liberty, the Coralville Reservoir, and the all-girl bagpipe band are mentioned in passing. 
Casey, John. CONNAISSANCE DES ARTS. In his Testimony and Demeanor, pp. 53-150. New York: Knopf, 1979. 207 pp.

A young drama teacher at The University of Iowa is involved with two coeds and he rescues one of them from an accidental balloon ride over fields, landing in the Iowa River. A visiting officemate develops a stammer. "She knew that the University of Iowa had a very advanced speech pathology center." A counterculture parade included "a man on a bicycle decked out with American flags. He was a figure about town-a harmless sparse-haired fellow who wandered about on his fat-wheel Schwinn with a large basket, picking through the trash baskets behind the stores."

Cassill, R.V. AND IN MY HEART. Paris Review 33 (1965): 27-156. Also in his The Father, and Other Stories, pp. 170-228. New York: Simon and Schuster, 1965. 254 pp. Also in his Collected Stories, pp. 135-85. Fayetteville: University of Arkansas Press, 1989. 642 pp.

A professor of English, said to be based on Edwin Ford Piper (1871-1939), who taught at lowa from 1905 until his death, is the hero. Like Professor Piper, the fictional professor is a poet from Nebraska, but he is a generation younger and the story is set in the 1950s. The physical setting is barely described but the unnamed school has a university hospital.

Cassill, R.V. THE CRIME OF MARY LYNN YAGER. In his The Happy Marriage, and Other Stories, pp. 21-45. West Lafayette, Ind.: Purdue University Studies, 1966. 122 pp. Also in his Collected Stories, pp. 367-89. Fayetteville: University of Arkansas Press, 1989. 642 pp.

A former schoolteacher, once an undergraduate at the University in Iowa City who went dancing at the Hawk Ball Room, returned to Iowa City. After interviewing for a sorority "housemother job, she got a decent kind of work in the bindery section of the University library" and "dated a tall, balding man in Cataloguing." Near "an ice cream drive-in," she heard "the thunder of water going over the dam by the power plant." 
Cassill, R.V. DORMITORY WOMEN. New York: Lion Books, 1954. $160 \mathrm{pp}$.

A panty raid at Blackhawk $U$ begins the action, which continues with several violent deaths. The Memorial Union footbridge connects the two sides of the campus and there are canoes full of students on the river. Two thousand students cheer at a pep rally and the football team loses to Notre Dame, 21-7.

Cathey, Bill Robert. THE COWBOY ANGEL RIDES. Ph.D. dissertation, University of Iowa, 1971. $160 \mathrm{pp}$.

A fictional graduate student in English writes about his lower-class landlady and her family and many of their personal problems. The house is south on Capitol Street near the Rock Island Railroad trestle. The student photographs a sad affair of a wedding at the tall red brick St. Patrick's Catholic Church, huge and lofty. The father of the groom did not know the name of the bride. The university is not mentioned.

Clark, Geoffrey. WHAT THE MOON SAID. Miscellany (Davidson, N.C.). Also in his What the Moon Said, pp. 30-52. Chicago: Story Press, 1983. 123 pp.

A graduate student in Iowa City remembers the pain of being 17 in rural Michigan.

Clothier, Peter. CHIAROSCURO. New York: St. Martin's Press, 1985. $259 \mathrm{pp}$.

Cynthia, a native of North Liberty, is a character in a mystery set in the art world of New York. "I had often reminded her that I had rescued her from the fate of completing a doctorate at the University of Iowa.

"That was in 'sixty-four. I had a residency there-a healthy chunk of salary for half a year, a respectable two-day teaching schedule with graduate students only, and a cramped but workable studio in a quonset hut down by the river. The 
students were reputed to be the pick of the crop. You could have fooled me. Barely a handful of them could draw."

Collins, Max Allan. THE DEALER. New York: Berkley, 1976. 188 pp. Also as Quarry's Deal. Woodstock, Vt.: Countryman Press, 1986. $188 \mathrm{pp}$.

Most of the action takes place in and near Des Moines, but two of the main characters come to lowa City and drink at the Airliner after a visit to The University of Iowa Psychiatric Hospital, described under its old name. "The Psychopathic Hospital at Iowa City was a sprawling one-story brick building on a spacious lawn whose many trees and bushes were apparently tailored to provide a soothing landscape, no matter what the season. Only right now it was no season at all, rather that limbo period between winter and spring, trees gray and skeletal, grass brown as cardboard. Even the few evergreen bushes looked wilted, like a salad that sat out."

Collins, Max Allan. MIDNIGHT HAUL. Woodstock, Vt.: Countryman Press, 1986. 218 pp.

Midway through this novel of suspense about toxic waste, the journalist hero eats at the Mill restaurant in Iowa City, "a late '60s time warp. The booths were displaced church pews; stained-glass panels hung behind the bar; a folksinger was doing something by Phil Ochs. . . . The food at the Mill was good, particularly the antipasto salad, and afterwards they would go to the Bijou Theater. . . ."

Collins, Max Allan. A SHROUD FOR AQUARIUS. New York: Walker, 1985. 174 pp.

The author's hometown, Muscatine ("Port City"), and Iowa City are the principal locations of this contemporary mystery novel. Collins plays with the alternate spelling of Old Capitol Center ("a vaguely institutional look - a mall in a police state"), Plaza Centre One, and the Civic Center. The interior and exterior of Bushnell's Turtle are shown in detail. Near that 
restaurant, "A new Holiday Inn loomed at our right, cutting across the plaza at an angle, a tan, modern building with lots of windows and along the side a restaurant with pregnant greenhouse windows. Iowa City so desperately wanted to be California, in the midst of a cornfield." The most important business establishment in the mystery is Things \& Things \& Things, disguised as ETC., ETC., ETC.

Collins, Max Allan. SPREE. New York: T. Doherty Associates, 1987. 311 pp.

The principal setting for this crime novel is a Davenport shopping center, but the Drake University campus, Des Moines, is just mentioned and there is an Iowa City antique shop operator and a breakfast eaten "at the Howard Johnson's near Iowa City" before the turn to highway 218.

Conroy, Frank. GOSSIP. In his Midair, pp. 87-121. New York: Dutton, 1985. 149 pp.

George, a writer, and his wife Kate are rescued from debt and a Maine winter by an offer to teach writing to "seventeen graduate students in a seminar workshop." The place is disguised as a "university in Kansas." The time in "[t]his lovely, quiet college town" is ten years after the "National Guard, riots, tear gas - the works."

Corey, Paul. COUNTY SEAT. Indianapolis: Bobbs-Merrill, 1941. 418 pp.

Paul Corey's Mantz trilogy of Iowa farm novels sends the youngest son of the Mantz family off to The University of Iowa in 1923 at the end of The Road Returns and follow him through to graduation in 1927 in County Seat. The student, Otto, appears mostly through letters and visits home to western Iowa. He works his way through school slinging hash, fixing phonographs, and working in a departmental library. His widowed mother proudly takes the train to Iowa City for commence- 
ment. "The huge concrete bridges across the Iowa River fascinated her; she liked to stand by the heavy railings and watch students canoeing."

Dubus, Andre. ADULTERY. In his Adultery \& Other Choices, pp. 129-78. Boston: D.R. Godine, 1977. 178 pp. Also in his Selected Stories, pp. 406-54. Boston: D.R. Godine, 1988. 476 pp.

When the novelist husband, Hank, was in Iowa City, "he was a young writer in a graduate school whose only demand was that he write, and write well. . . ."

Dubus, Andre. LOVE IN THE SKY. In his Andromache and Other Stories, pp. 41-67. M.F.A. thesis, University of Iowa, 1965. $111 \mathrm{pp}$.

The all-girl Scottish Highlanders, transplanted to Louisiana, perform at a football game in this short story about tension between a college student and his father.

Dubus, Andre. SEPARATE FLIGHTS. North American Review 255, no. 1 (Spring 1970): 10-26. Also in his Separate Flights, pp. 166-206. Boston: D. R. Godine, 1975. 206 pp.

An unhappy Iowa City wife and mother is very well portrayed with her thoughts and conversations. She and her husband take separate flights from the Cedar Rapids airport to a San Francisco insurance convention for the sake of their teenage daughter in case of a plane crash. The University is never mentioned and there is no description of the town.

Evans, Freeman. COVERED WAGONS. New York: Ballantine Books, 1984. 312 pp.

An English family moves to a farm near Iowa City in 1840, experiencing hardships and meeting escaped slaves and friendly Indians. Territorial Governor Robert Lucas, with his "thin and steady-eyed face," is a minor character worried about the "wretchedly incompetent construction work up at the new 
capitol" and wanting "to walk up a circular stairway that has no square corners!" A Black ironworker uses his skill to help build Old Capitol properly. Local historians will be surprised to read about the "intense building activity on both banks of the river" in booming Iowa City.

\section{Exley, Frederick. PAGES FROM A COLD ISLAND. New} York: Random House, 1975. 274 pp.

The author's reaction to the death of Edmund Wilson is the principal theme of this fictionalized autobiography, the second volume of a trilogy. The settings are Upstate New York, Florida, and Iowa City. Exley taught briefly at the Writers' Workshop, and the Iowa City locations in the book are his room at the Iowa House, the English-Philosophy Building, and downtown bars including Donnelly's. In one of the bars he meets the Epstein brothers, who operated a bookstore in Iowa City in the 1970s.

Glasser, William Arnold. NETHER MIND. Ph.D. dissertation, University of Iowa, 1965. $212 \mathrm{pp}$.

Nine pages of this creative dissertation are at "any Midwestern university," where the narrator and his wife rent an apartment on the hill above the river with views of the Gothic-towered hospital and the corrugated-metal shacks that are the school's married-student housing. Thousands of roosting blackbirds annoy the people of the town.

Godwin, Gail. A SOUTHERN FAMILY. New York: Morrow, 1987. 540 pp.

Clare, a Southern-born novelist caught in a family tragedy, during "a three-year teaching stint, winters and summers, at Iowa," gave a November visitor from the Carolinas "my L.L. Bean hunting jacket. All the writers in Iowa were wearing them that year." 
Grosso, Alfonso. OTONO INDIO: LOS CRIMENES DE LA RESIDENCIA MAYFLOWER. Barcelona: Planeta, 1983. 205 pp.

The Mayflower dormitory is home for the participants in the International Writing Program, founded by the late Paul Engle. Professor Engle is among the characters in this mystery, written in Spanish with the exception of untranslatable terms such as Kountry Kreations, located in Kalona. One year's group of novelists and poets from around the world make up the suspects and victims. Anton Shammas, whose Iowa City novel is also in this list, is a member of the group. Local settings include the "Antiguo Capitol," Hancher Auditorium, Best Steak House, Brown Bottle restaurant, and Micky's.

Grumbach, Doris. THE MAGICIAN'S GIRL. New York: Macmillan, 1987. 200 pp.

The lives of three Barnard College alumnae are spent mostly in New York City and upstate, but Minna, a professor of history at Brooklyn College, drives west to teach for a semester at The University of Iowa. Other New Yorkers confuse her destination with Ohio and Idaho. Minna watches the ducks from the cafeteria in the Iowa House and once she eats at an unnumbered Hamburg Inn. Minna writes that Iowa City is "astonishingly pleasant, a humane city with no traffic or pollution, no hassle, no crowds." The hills are "so steep in the city itself that it is a trial sometimes to climb them." Minor characters in the novel resemble Ezra Pound, John Gardner, and University of Iowa Professor Emeritus Byron Burford, an artist who loves the circus. The novel is best at its portrayal of childhood.

Guerrant, David. IOWA CITY STALKER. Campus Review 4, no. 5 (June 1988): 10-11.

The short story in the conservative student newspaper at The University of Iowa tells about an Iowa City policeman in the 
year 2088 assigned to kill several criminals, at least one of them with a name resembling a campus radical activist of the present.

Hardwick, Elizabeth. THE SIMPLE TRUTH. New York: Harcourt, Brace, 1955. 223 pp.

In late 1949 a fraternity member in Iowa City was accused of killing his sorority girlfriend. The 1950 murder trial was sensationally reported by big-city newspapers. In this novel based on that trial, a married graduate student and a faculty wife attend the trial together and discuss courtroom activity and life in the Iowa town that is the home of the State University. The student and his own wife were squeezed into a one-room apartment. "Although only of moderate size this single room had so many recesses given over to some function of housekeeping usually placed alone that there was hardly anything, unless it might be the little spot in the center covered with a tiny, red tufted rug, that could properly be called the living room itself."

Most of the transients in this university town "simply abhorred the place with a manic volubility. The aliens who had settled for good had more troubled minds, recalling sometimes with a sigh the lost hills and bays of San Francisco, horseback riding in Arizona, and most of all the great East from the Green at Concord to the steak and fish houses of Baltimore. . . Here also at the University were many teachers from Europe ... remarkable souls pacing the Iowa pavements. ... They were in America, no doubt about that, even if perhaps they had not bargained for so completely the real thing and wondered at their fate."

Harter, Evelyn. DR. KATHERINE BELL. Garden City, N.Y.: Doubleday, 1950. 274 pp.

Katherine Bell is a woman doctor from lowa in a novel by a physician's daughter who became a book designer. The early pages cover Katherine's student years in the early 1920s at Sioux University on "Lake Sioux, where the university buildings and the business part of Prairie City lay stretched and 
intermingled along the southern tip of the lake." Some of the action takes place in the women medical students' rooming house and in a popular restaurant. "Sobi's Restaurant was directly across from the Arts campus, and a block from the medical college, a group of old brick buildings weakly Gothic in architecture. The restaurant stood at the junction of two main highways and drew its clientele from students, truck drivers, and townspeople."

Irving, John. THE WATER-METHOD MAN. New York: Random House, 1972. 365 pp.

This early John Irving novel is about a Ph.D. candidate in comparative literature at The University of Iowa who lives at 918 Iowa Avenue and sells football pennants. The wounded hero, carrying a dead duck, looks "across the river, on the bank that looks like an Army barracks - stacked with the war-built Quonset huts, now called Married Student Housing. . . ."

Irving, John. THE WORLD ACCORDING TO GARP. New York: Dutton, 1978. 437 pp.

T.S. Garp, an Eastern novelist, in the first chapter of his The World according to Bensenhaver (in reality a chapter of John Irving's novel), writes about a visiting professor looking out of his office window in what might be the English-Philosophy Building in a university town near a smaller town named Hills. Garp's father-in-law "had been a two-time Big Ten wrestling champion at the University of Iowa." The motion picture version of The World According to Garp omitted the Iowa City connection.

Jeffery, Ransom, and John Keeble. MINE. New York:

Grossman, 1974. 280 pp.

Hills, Oasis, and Iowa City are all settings for Mine. Sand Road, the bus terminal in "the back room of a semidefunct hotel" [the Burkley Hotel, now demolished], football Saturdays, and a demonstration at the Student Union are in the 
background. A minor character is upset because urban renewal will take away Irene's bar. "Put the little man out of business. They haven't got the right. Over twenty years this place has been an institution. By God, Tennessee Williams drank beer here. ... Phil Roth was a customer too. Flannery $\mathrm{O}^{\prime}$ Connor. Bill Williams. Nelson Algren. Richard Hugo. Jim Whitehead. See those pictures on the wall? ... Ferlinghetti and Ginsberg come by whenever they're in town. Saul Bellow, too."

Johnson, Denis. WORK. New Yorker 64, no. 39 (November 14, 1988): 36-38.

The work is done by a couple of customers of the Vine tavern in a college town in Iowa. "Because of urban renewal, the whole downtown was being torn up and thrown away." There is "a cool river shaded by benevolent clouds" and a Holiday Inn.

King, Stephen. THE LIBRARY POLICEMAN. In his Four Past Midnight, pp. 401-604. New York: Viking, 1990. 763 pp.

A character in this tale about a small-town Iowa public library "had graduated from Iowa City Business College. . . ." Cedar Rapids and Des Moines are also mentioned.

Kinsella, W.P. DISTANCES. Sport Magazine. Also, revised, in his The Further Adventures of Slugger McBatt: Baseball Stories, pp. 1-24. Boston: Houghton Mifflin, 1988. 179 pp.

This short story is set after the 1950s at Onamata, near Iowa City, mentioning the University of Iowa ball club and the Procter and Gamble team in a commercial league. 
Kinsella, W.P. FRANK PIERCE, IOWA. In his Five Stories, pp. 4-13. Vancouver, B.C.: W. Hoffer/TANKS, 1986. 57 pp. Also, revised, in his The Further Adventures of Slugger McBatt: Baseball Stories, pp. 63-74. Boston: Houghton Mifflin, 1988. $179 \mathrm{pp}$.

Kinsella explains the disappearance of Frank Pierce, Johnson County, and its baseball diamond in 1901. (The real Frank Pierce was renamed Frytown, still there.) "If you consult the list of Abandoned Post Offices in... the University of Iowa library in Iowa City, you find that the Frank Pierce Post Office came into being in 1895 and was abandoned in 1901."

Kinsella, W.P. THE IOWA BASEBALL CONFEDERACY. Boston: Houghton Mifflin, 1986. 310 pp.

This baseball novel, like Kinsella's earlier Shoeless Joe, is set in and near Iowa City. Pearson's Drug Store is praised again. "Tall chocolate malts, thick as cement, served in perspiring glasses." The Airliner, a student bar, and Bushnell's Turtle, a restaurant, also appear. The baseball league of the title was founded in 1902, perhaps in Donnelly's Bar, by Clarke Fisher Ansley and Frank Luther Mott. Ansley, professor of English, was a founder "of what eventually became the Iowa Writers' Workshop," and Mott, in Iowa City a generation too early, headed the School of Journalism. The league's end came in a prolonged game with the Chicago Cubs, July 4, 1908. Leonardo da Vinci, who invented baseball in 1506, observes the game through a crack in time and the Black Angel "was a good right fielder. ..." The village of Frank Pierce (now Frytown) and "Max Yocum, the house mover from Iowa City," are mentioned.

Several excerpts appeared before publication of the novel itself. 
Kinsella, W.P. SHOELESS JOE. Boston: Houghton Mifflin, 1982. 265 pp.

"Is this heaven?" No, but "Field of Dreams," the motion picture version of Shoeless Joe, gave Iowa a great promotional slogan.

A Canadian student at the Iowa Writers' Workshop, W.P. Kinsella wrote a novel combining J.D. Salinger, baseball, and corporate farming. The title comes from Shoeless Joe Jackson of the Black Sox of 1919. Kinsella's hero, Ray Kinsella, "came to Iowa to study, one of the thousands of faceless students who pass through large universities, but [he] fell in love with the state." His depiction of a real Iowa City mentions Old Capitol, West High School, Iowa City glass, the Iowa Theater, Donnelly's Bar, and the public and University libraries. The author was mistakenly led to believe that Iowa City, not Mason City, was Meredith Willson's River City in The Music Man. "Shady streets, very old white frame houses, porch swings, lilacs, one-pump gas stations, and good neighbors.... We have a drugstore with a soda fountain. . . It's dark and cool and you can smell malt in the air like a musky perfume. And they have cold lemon-Cokes in sweating glasses, a lime drink called a Green River, and just the best chocolate malts in America. It's called Pearson's - right out of a Norman Rockwell painting."

\section{Kopp, Frederick. SOMETHING LIKE THIS HAPPENS EVERY WAR. Glendale, Calif.: Great Western Pub. Co., 1982. $181 \mathrm{pp}$.}

A novel about two wounded officers returning from the Vietnam War to academia (reminding one of Kent State) mentions in passing an army surgeon, "a mere graduate of the University of Iowa Medical School." According to the author (M.A., Iowa, 1941), several of the characters were based on people he knew at The University of Iowa. 
Lafore, Laurence D. NINE SEVEN JULIET. Garden City, N.Y.: Doubleday, 1969. 300 pp.

A retired professor of literature at the state university, once a pilot and now living on a farm at the age of 80 , is the hero of a mystery by Lafore, late professor of history at The University of Iowa. "The city of Buchanan and Van Buren County bear some general resemblance to Iowa City and the beautiful country around it but the details . . . are imaginary," according to the author's introduction. The title is part of the serial number both of the light plane owned by Lafore and of a similar airplane in the novel. Another academic novel by Professor Lafore, perhaps set at Trinity College, Hartford, Connecticut, is Learner's Permit. Garden City, N.Y.: Doubleday, 1962. $308 \mathrm{pp}$.

Leavitt, David. EQUAL AFFECTIONS. New York:

Weidenfeld \& Nicolson, 1989. 268 pp.

April, a lesbian folksinger, gets letters and poems from women all over the country. One is Sonia, "the woman with red hair in Iowa City," at a juice bar. On tour, April writes her homosexual brother, "We are in Iowa City. I sip orange juice at the Six-Twenty. ..." April's lovers are most often in "small towns-Iowa City and Northampton and New Haven-places where rents were cheap and universities predominant; places where, in earnest, women who love other women had been for years collecting." Local readers may think that the cheap rents are fictional.

LeBlanc, Liz. DANCING IN IOWA CITY. In her No Mean Feet, p. 11. Salome 38. Dialogues on Dance 4. Chicago:

Ommation Press, 1985. 13 pp.

Poets dance to records of the Grateful Dead.

"dancing at that stiff poet's party

in Iowa City Ioway." 
Leggett, John. MAKING BELIEVE. Boston: Houghton Mifflin, 1986. 295 pp.

A clergyman whose career parallels that of controversial Bishop James A. Pike (1913-69) serves as rector of green clapboard Trinity Episcopal church in a section of this novel by the former director of the Iowa Writers' Workshop. The clergyman is at the center of the student antiwar demonstrations in "Iowa City, a turn-of-the-century town whose Victorian rooming houses and maple-shaded walks still held out against the bulldozers and transit-mix concrete trucks. A gold-domed Old Capitol building presided over a University which sprawled along both banks of the Iowa River. On its steps a hoarse speaker was haranguing a circle of thirty students.

"Facing it the town appeared to be under siege. In a doorway a merchant swept shattered glass into a dustpan. Many show windows had been replaced by widths of plywood. The few which had been spared were protected by embrasures of chickenwire. . . . There was a smell of destruction in the air."

\section{Lehrman, Robert. DEFECTORS. New York: Arbor House,} 1988. 286 pp.

A track and field novel is told by a University of Iowa junior, the American record holder in the mile. Set in 1958 and 1959, the novel is about the defection of a Russian runner, friendship, and personal values, against a background of partisan politics, winter weather, and privileges for varsity athletes. The author moves the women's dormitories and a favorite bar to a different downtown street, describing "the Airliner, a student bar on College Avenue where Elvis Presley 45s were always spinning in the jukebox, and where jocks came to eat tenderloins so big they flopped out over the edges of the bun." The runners can see "the corrugated tin barracks where the English department was housed. . . ." Also at the university, "Some of the Rhetoric teachers were drawn from the Writers' Workshop, a program filled with tattooed ex-Marines and Jews from New York who somehow sat in classes together without killing each other." 
Liljenquist, Don. THE CHANCELLOR'S PARTY: IOWA'S PRIZE-WINNING CENTENNIAL PLAY. Salt Lake City: Playwrights' Press, 1949. 132 pp.

The play was performed at the Mabie Theatre on the onehundredth anniversary of the founding of The University of Iowa. The re-named and fictionalized characters are involved in a crisis in the university's history. The first president, or chancellor, Amos Dean, about to return to his Albany Law School in 1856, wants to close down the frontier university. More progressive educators on the faculty fight to keep the school open for the teaching of new ideas and new subjects. All of the action is set in the house of Professor Stone. Jared M. Stone's wife and children and their hopes, fears, and romances over the course of a single day give life to the battle over educational philosophy.

Lowe, Tower. THE CALIFORNIA KILLER. Alfred Hitchcock's Mystery Magazine 30, no. 5 (May 1985): 47-58.

A murder investigation begins in January at twelve below zero. Locations include the Biology Building and "a newly-built brick complex on Iowa Avenue.'

McDonald, Julie. REACHING. Montezuma, Ia.: Sutherland Publishing, 1988. 202 pp.

A Danish Baptist girl, Margaret Langelund, from Harlan (the author's home town), goes to The University of Iowa for her freshman year in the late 1940s, meets many other students, has new experiences, overcomes embarrassing incidents, and becomes more mature by the start of her second year. Just before her sophomore year, she works as a legal secretary in a murder trial strongly resembling the real-life case in Elizabeth Hardwick's The Simple Truth.

The Lark restaurant in Tiffin, Professor Mosse of history, and "the golden dome of Old Capitol" are mentioned in passing. A glass of wine with a dinner at the Lark may be an anachronism. "There never seemed to be time to contemplate the pool below the Law Commons with its rugged rock wall, to cut through the 
art building and smell the paint, to mosey across the acres of formally-patterned carpet in the Union ballroom."

McMenamin, Thomas John. CALL ME MANNESCHEWITZ. New York: Scribner, 1971. 239 pp.

An M.F.A. candidate in pottery in Iowa City is the hero, though the novel has very little on either the town or the University.

McMillen, Howard. THE MANY MANSIONS OF SAM

PEEPLES. New York: Viking Press, 1971. 299 pp.

Samuel T. Peeples is a landlord in the college town of Kanecka City, Kansas. "The group of four buildings Peeples called the White House, the Brownstone, the Cottage, and the Chicken Coop were referred to sarcastically by the residents of Kanecka City as Peeples' Paradise. Peeples had adopted the name as his own creation. ..." The property bears strong resemblances to Black's Gaslight Village in Iowa City. Many of the townspeople have Czech names.

McMurtry, Larry. MOVING ON. New York: Simon and Schuster, 1970. 794 pp.

Texas novelist McMurtry sends a couple from Rice University northward in Moving On. "Flap had worked hard on his dissertation and had two chapters done and only three to go, and he had secured a job, a better one than he had expected, at the University of Iowa, in Iowa City. Emma was gloomy for a few days at the thought of Iowa, but then someone told her that there was a big writing center there, with hundreds of lively writers in it. The news cheered her a bit. Shé sat around for several days reading Letting Go and imagined herself slimmed up and having an affair with a young writer of some kind." The characters from Moving On reappear in other McMurtry novels, and in his Terms of Endearment, made into an award-winning motion picture, Flap teaches at colleges in Des Moines, Iowa, and Kearney, Nebraska. 
Morrell, David. BUT AT MY BACK I WILL ALWAYS HEAR. In Ghosts of the Heartland: Haunting, Spine-Chilling Stories from the American Midwest, edited by Frank D. McSherry, Jr., Charles G. Waugh, and Martin H. Greenberg, pp. 1-17. Nashville: Rutledge Hill Press, 1990. 210 pp.

"I'm from Iowa City, Iowa. I teach-or used to teach until three days ago-creative writing at the University." The professor is threatened by an obsessed female student who chases him to his office (the stairwell has "walls of pale-red cinderblock"), his home, and far beyond.

Mossman, Dow. THE STONES OF SUMMER: A YEOMAN'S NOTES, 1942-1969. New York: Bobbs-Merrill, 1972. 552 pp.

Characters from Rapid Cedar drive thirty miles to Iowa City to get drunk in December. When they leave the bar "it must have been twenty below zero, and Dawes noticed a clock on one of the banks had frozen up and stuck." After snapping off a car door on an old-fashioned high curb, they roar back to Rapid Cedar "without a door, cold as hell. . .."

Mukherjee, Bharati. JASMINE. New York: Grove Weidenfeld, 1989. 241 pp.

A young widow from India, whose life is surrounded by violence and its victims, escapes to Iowa, which is not flat, during the farm crisis and further violence. She finds peace and love after asking for work at the University Hospital. Fans of rival baseball teams, Cardinals and Cubs, can submerge their loyalties in the Hawkeyes. The dedication to an Iowa City bookstore proprietor is: "For Jim Harris, ardent Hawkeye." Bharati Mukherjee is the wife of author Clark Blaise.

Murphy, Robert W. A CERTAIN ISLAND. New York: M. Evans, 1967. 239 pp.

The Laysan Island cyclorama, in The University of Iowa Museum of Natural History, Macbride Hall, is the result of a collecting expedition by the museum in 1911. This juvenile 
novel is about a follow-up expedition to Laysan, now part of the Hawaiian Islands National Wildlife Refuge. The hero, a freshman at the University in a little college town on the Iowa River, "bears some outward resemblance to Alfred M. Bailey . . the Director of the Denver Museum of Natural History." Bailey (1894-1978), an Iowa City native, was a member of such an expedition, 1912-13. The hero's mother buys her furniture at the Amana Colonies. The author repeats the discredited theory that the Mound Builders were not Indians.

Nelson, Peter N. COOLEY AND KEDNEY. Iowa Review 14, no. 1 (Winter 1984): 73-102.

The Black Angel in an Iowa City cemetery, the University Hospitals' sperm bank, and the poet-activist David Sundance appear in the story of a fictional poet and her enduring love for an art department photographer killed in a plane crash near Cedar Rapids. She moves around the country but returns to Dubuque for happy memories and to Iowa City "to teach at the same Writers' Workshop she'd graduated from. ..."

Newborn, Sasha. THE BASEMENT. Santa Barbara, Calif.: Mudborn Press, 1978. 179 pp.

The Basement interweaves experiences as a teacher in Africa with life in a basement apartment on Iowa Avenue, Iowa City, in half a block of houses torn down by the city for more parking space, leaving the Unitarian Church on the corner. The narrator sees a "chair broken by Vonnegut or Roth" - and Bourjaily once spoke to him!

Nieh, Hualing. MULBERRY AND PEACH: TWO WOMEN OF CHINA. Boston: Beacon Press, 1988. 207 pp.

This novel by the retired director of the International Writing Program at The University of Iowa ends with a Chinese widow living in Lone Tree, Iowa (big enough to have a parochial high school and one-way streets), surviving an automobile accident, and escaping from Mercy Hospital. Perhaps her "Lone Tree" is 
inspired by Iowa City. Mulberry and Peach was written and published in Chinese and translated into English (first published in 1981) and other languages.

Olsen, Lance. LIVE FROM EARTH. New York: Ballantine Books, 1991. 196 pp.

Bink Fischer, a native of Des Moines, returns from Vietnam in 1973 to be accepted by "the Writers' Workshop at the University in lowa City" where he has a teaching assistantship. "He rented a neat apartment in a brick building on Woodside Drive a block from a small park with two swings in it. The town reminded him of photographs he had seen of Hiroshima the day after they dropped the bomb, virtually no traffic, a barren landscape, a number of half-finished construction sites." The time is during lowa City's urban renewal period.

"Every Tuesday afternoon he walked to campus, up the poorly lit stairs of the English-Philosophy Building, down the dim brick-lined hall, and into a white room where fifteen other writers had gathered." The novel has briefer mentions of Grinnell College and the University of Virginia. Virginia becomes Bink's base for his save-the-whales campaign.

Porter, William E. HIDE-OUT. Saturday Evening Post 218, no. 24 (December 15, 1945): 12-13, 52, 54, 56-59, 62, 65; no. 25 (December 22, 1945): 28-29, 76, 79-80, 82, 84, 87-88; no. 26 (December 29, 1945): 28-29, 39, 41, 44; no. 27 (January 5, 1946): 28-29, 70, 72-74, 76 .

The author, who rose to the rank of professor of journalism at Iowa and is now retired from the University of Michigan, told his local readers that the setting, Hilltop, Iowa, was not modeled on Iowa City, but the local newspaper is the Citizen. In this serial, the Lost Indian River "nicks a corner off the Gideon College campus." The characters include jewel thieves, murderers, and a college president who will do almost anything for contributions. The climax is at the college commencement. Near Hilltop is "the tractor plant in Cedar Rapids," where there has never been such a factory. 
Racine, David. BO KNOWS FICTION. New Yorker 66, no. 5 (March 19, 1990): 38-40.

Bo, writer and baseball and football player, performs with his Smith-Corona at Madison Square Garden in front of a raucus crowd of New Yorkers. Joyce Carol Oates provides the color commentary for the National Public Radio play-by-play broadcast. New York is the second stop and lowa City will be the fourth on Bo's six-city itinerary across the country before his summer of creativity is published by E.P. Dutton. "The Iowa stop, at Carver-Hawkeye Arena, on the University of Iowa campus, has been sold out for weeks."

Rhodes, David. ROCK ISLAND LINE. New York: Harper \& Row, 1975. 379 pp.

Sharon Center, Iowa, and Philadelphia, Pennsylvania, are the settings, but the Iowa City railway station is the scene of key transitions in the life of a small boy growing to young manhood. His description of Iowa City is concise. "Not big. There's a university there. That's nearly as big as the whole town."

Roth, Philip. LETTING GO. New York: Random House, 1962. 630 pp.

Letting Go opens at The University of Iowa in the fall of 1953. The hero and his friends are graduate students, living in apartments and in married students' barracks. Coe College, where one student also teaches, and Dubuque Street are named, but Roth concentrates on the lives of his characters rather than on the setting.

Sandroff, Ronni. PARTY PARTY: GIRLFRIENDS: TWO SHORT NOVELS. New York: Knopf, 1975. 196 pp.

Both novelettes are set in Candle City, Iowa, which has the Mainliner bar and College and Market streets. One can walk "down past the hospital complex, under the campus elms, past the girls' dormitories into the suppertime emptiness of the 
downtown area." Among minor characters in Party Party, "Kenny Loren owns a bookstore in town and prints the local Socialist sheet in his cellar. He's forty years old." Some readers may be reminded of the now-defunct Paper Place bookstore.

Shammas, Anton. ARABESQUES. New York: Harper \& Row, 1988. 263 pp. An excerpt was published as "The Storyteller, Mayflower," in The World Comes to Iowa: Iowa International Anthology, edited by Paul Engle and Rowena Torrevillas, pp. 66-74. Ames: Iowa State University Press, 1987. 295 pp.

The original novel here translated into English is remarkable for being written in Hebrew by an Israeli Christian Arab. It was published in Tel Aviv in 1986 and was a best-seller in Israel. Four sections of Arabesques are set at the Mayflower dormitory at The University of Iowa, where the author, like his namesake character, attended the International Writing Program and met Paul and Hualing Nieh Engle. "There is a special savor to evenings at the Engles'."

Along the ride downtown from the Mayflower, past the white houses, "[s]quirrels rushed about at the feet of the trees, their tails erect with midwestern pride." Later in the program, "the red hush of Indian summer in the foliage of the maples ... pauses over the waters of the river and floats down with the falling leaves." Soon after, "[w]inter shows the first signs of its coming, then lurks in ambush behind the thinning foliage."

Shattuck, Katharine. THE NARROWEST CIRCLE. New York: McDowell, Obolensky, 1958. 279 pp.

A professor and his wife and daughter and their guest, a young woman who has completed her student years, spend a summer in the country at a stone mansion above Rockville, Kansas, a quarrying ghost town. The setting strongly resembles Paul Engle's former summer house at Stone City, Iowa, "the stone church with its square tower ... the single winding road on which the town was strung . . most of all the mansion house on the hill." At the end of the summer the group returns 
to an unnamed university town with a hospital hill. Robert Frost was at a party in the town a few nights before the novel began.

Shields, David. HEROES. New York: Simon and Schuster, 1984. 347 pp.

To date, the only UI basketball novel is Heroes. A sportswriter for the River City Register investigates a recruiting scandal involving the River State University Stallions, an Oxford, Iowa, philanthropist who "gets hospital wings named after him," and the reporter's own wife, who hopes to get tenure in English. The reporter, his wife, and their seven-year-old diabetic son are unusually appealing fictional characters in their reactions and weaknesses. The novelist condemns the Downtown Refurbishment Project, which gutted the best bar in Johnston [sic] County. "The pedestrian greenway and Sycamore Mall and Plaza Center [sic] One have ruined this town, and now the Old Capitol Center promises to bury it under eight feet of cement." His newspaper's wackiest columnist, Susie Smyth, "takes her show-stopping vamp-stripper parody to motel lounges and bars around town." River City has the River State Clinics, KHAK and KRNA, the downtown Rec Center, the Coralville Strip (studied by a university class), and the Coralville Reservoir.

Siciliano, Sam. BLOOD FARM. New York: Pageant Books, 1988. 336 pp.

You think the farm crisis was bad? This "Iowa Gothic" horror novel's circumstances are much worse. Angela, the heroine, is hitching to Iowa City on the interstate on a below-zero February night in 1972 when she becomes the prisoner of a vampire. Angela's boyfriend seeks help in Iowa City at Center East, the former Catholic Student Center. "The black metal of the fire escapes zigzagged back and forth, stuck to the flat wall of red brick." Nearby were the dormitories, "modern edifices of glass and gaudy orange brick," the Green Cross drugstore, an unnumbered Hamburger Inn, and the Congregational Church, 
"the gray-brown building complete with ornate windows and a pointed steeple." The novel is dedicated to Professors Archibald Coolidge and W.R. Irwin.

Silkman, Anne. HERKY: A BIOGRAPHY. Illustrated by Nori Cornick. Fort Madison, Ia.: Foley Printing and Graphic Design, 1984. 32 pp.

Herky, son of Tommy and Kitty, was a "special baby hawk." "One day, while Herky was on a training flight with his dad ..." over a rectangular stadium, he "dove to where he could see men in black and yellow uniforms running and falling and kicking. He could hear cheering and yelling. It was so exciting!" Herky, whose life is told in cartoons, worked hard to be a Hawkeye, becoming a student, football and basketball player, and wrestler. His younger sister Holly is headed for the women's basketball team.

Spivak, Talbot. THE BRIDE WORE THE TRADITIONAL GOLD. New York: Knopf, 1972. 196 pp.

The bride teaches Sanskrit poetry to Iowa undergraduates while her husband commutes to teach drugstore Latin at a liberal arts college sixty miles south of their Johnson County farmhouse. Augustana College, Rock Island, Illinois, may be its model.

Stegner, Wallace. BEYOND THE GLASS MOUNTAIN. Harper's Magazine 194 (May 1947): 446-52. Also in his The Women on the Wall, pp. 1-14. Boston: Houghton Mifflin, 1950. 277 pp.

Two alumni, an Iowa City businessman and a Yale professor, meet after 17 years apart. The visitor from Yale "found himself at the corner of College and Dubuque Streets in Iowa City, at a little past ten on a Sunday morning in May, and as he stopped on the corner to let a car pass, the utter and passionate familiarity of everything smote him like a wind. ...the stone lace of the hospital tower ... the union and the reserve library 
[Old Armory] strung out along the riverbank. . . ." He climbed the hill to the field house. "He would have liked to go in under the big round roof just to soak himself in the sensations he remembered: smell of lockers opened on stale gym clothes and stiff sweated socks; steam and thumping radiators and liquid soap smell; sweat and medicated foot baths and the chlorine smell and the jiggly reflecting chemical blue of the pool. . .."

Stegner, Wallace. CROSSING TO SAFETY. New York:

Random House, 1987. 277 pp.

The first part of the novel is set at the University of Wisconsin in the late thirties, with Madison locations and two of its four lakes, Mendota and Monona. However, the narrator is said to be Stegner himself and another major character, Sid Lang, is said to be modelled on the late Wilbur Schramm, professor of English, first director of the Iowa Writers' Workshop, and director of the School of Journalism before leaving for a distinguished career at other universities. The sailboat sinking on page 114 is supposed to have really happened on Lake Macbride, near lowa City.

Stegner, Wallace. FIRE AND ICE. New York: Duell, Sloan and Pearce, 1941. 214 pp.

Stegner, who earned his M.A. and Ph.D. degrees at lowa and who became a distinguished novelist and teacher of writing at Stanford University, wrote Fire and Ice about a desperately poor freshman active in the Young Communist League while holding down several student jobs at once. There is little physical description of the campus (or is it Wisconsin?) and town but Stegner finely portrays the mind of his fictional student and the reactions of the other characters. 
Stegner, Wallace. THE VIEW FROM THE BALCONY.

Mademoiselle 27, no. 3 (July 1948): 68-70, 103-9. Also in his The Women on the Wall, pp. 93-120. Boston: Houghton Mifflin, 1950. 277 pp.

An English war bride is among a group of married graduate students, all veterans, and their wives living in a fraternity house for the summer. Their Graduate School is in Indiana but across the highway and the Wawasee River beyond is a city park with lions roaring in the zoo.

Strieber, Whitley. BILLY. New York: Putnam, 1990. 317 pp.

A mass murderer of boys kidnaps a small town Iowa boy, Billy. Billy's father, a high school history teacher, is frequently fired for his liberal political views. He was recently fired in Iowa City, a town not otherwise described in this vividly detailed novel.

Sunwall, James Raymond. MARCHING AS TO WAR. Ph.D. dissertation, University of Iowa, 1962. 313 pp.

A veteran becomes an aide at the new (in 1951) Veterans' Administration hospital on the hill above the sickle-shaped drive in Center City. The aide had been a student at the University, taking classes on the other side of the Iowa River. On July 4 he watches the fireworks in Riverside Park, near the zoo.

Twito, Tom. EXCERPTS FROM THE AUTOBIOGRAPHY OF CONSTANCE TURABIAN. Vital Signs (April 1982): 1, 6.

A short story in the medical students' newsletter is a parody set against the background of the fictional University of Iowa Sportswriter's Workshop. Characters include not only writers but such sports artists as Lasansky, designer of football programs, and Frank Miller. Conversationalists include F.J. Hastings, who "was always agreeing in those days," Roy Carver, sports fan James Van Allen, and Meredith Willson. 
Wakefield, Dan. HOME FREE. New York: Delacorte Press, 1977. 245 pp.

The ex-student hero spends the fall of 1970 in Iowa City as part of a year-long journey that begins in Urbana, Illinois, and ends in Los Angeles with long stopovers in Boston and in Maine. The author has a good eye for local detail. Donnelly's Bar, soon to be lost to urban renewal, appears along with the Airliner. "There were old-fashioned hardware and dime stores with wooden floors, bars with billiard tables, diners that served homemade chili, the Epstein Brothers' homey bookstores where you could browse all day without being hassled."

Wallis, Ruth Sawtell. COLD BED IN THE CLAY. New York: Dodd, Mead, 1947. 212 pp.

The author, who was an anthropologist at the Iowa Child Welfare Research Station, 1929-31, at the beginning of her college teaching career, combines elements of more than one college town in this academic mystery set near the end of World War II. "A State University was holding its annual commencement. . . . Flat in the middle of the U.S.A., a college campus ought to meet a cornfield. Corn paid taxes and taxes paid for the pomp and circumstance which the student band was demanding for the boys and girls. . . . In June, 1945, less than one in ten of these graduating seniors was male." Among the graduate degrees is a Master of Child Welfare.

Welt, Elly. BERLIN WILD. New York: Viking, 1986. 368 pp.

A Jewish survivor of World War II in Berlin, where he was a teenager protected at the Kaiser Wilhelm Institute, becomes an anesthesiologist, moving down from McGill to The University of Iowa College of Medicine in 1967. During a day of personal crisis, he rushes from the hospital complex to the business district, crossing "the little ravine, the overpass over Riverside Drive, the Iowa Avenue bridge over the river, up the steps of Old Capitol, and a cut through the Pentacrest." Downtown he enters Varsity Book, a textbook monopoly with windows broken by antiwar protesters, reminding him of Kristallnacht, 
and sees yellow and black clothing "with the university logo, an ugly beaked hawk." Poetry books are sold up Clinton at Epstein's. Another slight anachronism for 1967 is the Cambus. The long day ends with a prayer service at Agudas Achim on Washington Street. The Spanish physician in the author's Joanna Reddinghood appears as a minor character in this novel.

Welt, Elly. JOANNA REDDINGHOOD. New York: Random House, 1980. 314 pp.

A publishing party with a flock of English professors and the staff of the Writers' Workshop is a highlight of a medical murder mystery featuring a Spanish anesthesiologist at the University Hospital, University City, who owns three farms and subscribes to Wallaces Farmer.

Weverka, Robert. THE STORY OF BILL. New York: Bantam Books, 1983. $184 \mathrm{pp}$.

Bill Sackter (1913-83) operated the coffee shop in The University of Iowa School of Social Work after his release from mistaken institutionalization in Minnesota for forty-four years. Bill became one of Iowa City's most beloved and celebrated citizens. His life was the subject of two television docudramas. This novel, based on the television scripts, outraged Bill's friends. The author never interviewed anyone who knew Bill and the novel adds nothing about Bill's life not covered in the scripts. The reader will learn little about Iowa City.

Will, Frederic. BACK TO IOWA. In his A Portrait of John: The Midwest and the World (1928-1989), pp. 93-105. Detroit: Wayne State University Press, 1990. $162 \mathrm{pp}$.

"John," a Comparative Literature professor who resembles the author, "rolled into Iowa City" to direct the Translation Workshop. "What a town Iowa City was, with its magical blend of pedant-redneck-poet-hick! Everything was alive. . . ." John spent "four years in the gold-domed shadow of the Iowa State Capitol. . .." 
Wirt, Mildred A. GHOST GABLES. Cleveland: World Publishing Company, 1939. 205 pp.

Ghost Gables begins at the boat landing on "the winding Big Bear river which flowed through the town, dividing the campus of Ardmore college." The tomboy heroine of this mystery story for girls rents canoes to students for her father. She helps a new friend, a freshman, turn a mysterious old house into a rooming house for other women students. There is a "secondhand book store on Clinton street" in Ardmore.

Yates, Richard. THE EASTER PARADE. New York: Delacorte Press, 1976. 229 pp.

The younger of two sisters follows a divorced Yale Younger Poet west when he is invited to teach at the Iowa Writers' Workshop. They rent a former artist's studio out in the country. "Iowa City was a pleasant town, built in the shadow of the university along a slow river. Some of the straight, tree-lined, sun-splashed residential streets reminded Emily of illustrations in The Saturday Evening Post. . . ."

Yoseloff, Martin. WHAT ARE LITTLE GIRLS MADE OF? South Brunswick, N.J.: A.S. Barnes, 1979. 214 pp.

A Miss Iowa candidate lives at the Fenmore Women's Dormitory as a senior at Iowa $U$, soon to marry her steady. The route to Cedar Rapids, the contest site, "was fraught with sudden turns. The road would be icy; maybe there'd be snow." On the raw winter day, the campus had rolling hills, bare trees, and "icicles hanging from the roof of the Haver Literature Building. . . ." 